\title{
Akashiwo sanguinea (Dinophyceae) blooms in a sub-tropical estuary: An alga for all seasons
}

\author{
Susan Badylak ${ }^{1}$, Edward J. Phlips ${ }^{1, *} \&$ A. Loren Mathews ${ }^{2}$ \\ ${ }^{1}$ Fisheries and Aquatic Science, School of Forest Resources and Conservation, University of Florida 7922 NW 71 St. \\ Gainesville, Florida, 32653, USA \\ ${ }^{2}$ Georgia Southern University, 1332 Southern Drive, Statesboro, GA 3045, USA
}

Received 7 February 2014; Accepted 14 July 2014

\begin{abstract}
Akashiwo sanguinea is a cosmopolitan dinoflagellate that has been observed to form major blooms in coastal ecosystems around the world. A. sanguinea plays a major role in the ecology of many marine environments, including coastal ecosystems with variable salinities, where its euryhaline character makes it competitive. The study involved monthly water sampling and measurement of physical-chemical parameters at four sites from the upper reaches of the Caloosahatchee Estuary to San Carlos Bay bordering the Gulf of Mexico. Major A. sanguinea blooms were observed in the Caloosahatchee estuary, with biovolume up to $30.5 \times 10^{6} \mu \mathrm{m}^{3} \mathrm{~mL}^{-1}$, equivalent to $740 \mathrm{cells} \mathrm{mL}^{-1}$, in the upper estuary. The latter regions of the estuary also had the greatest range of salinity and the highest total nitrogen and total phosphorus concentrations. The dynamics of blooms are discussed within the context of spatial and temporal patterns of salinity, temperature and nutrient concentrations, as they relate to hydrologic and climatic conditions.
\end{abstract}

Key words: Akashiwo sanguinea, Caloosahatchee Estuary, dinoflagellates, Florida, phytoplankton

\section{Introduction}

The dinoflagellate Akashiwo sanguinea (Hirasaka) G. Hansen \& Moestrup plays a major role in the ecology of many marine environments, including coastal ecosystems with variable salinities, where its euryhaline character makes it competitive (Steidinger \& Tangen 1996, Matsubara et al. 2007, Phlips et al. 2011, 2012). Gymnodinium sanguineum was first reported as a red tide-forming organism along the coast of Japan (Hirasaka 1922). It was later renamed A. sanguinea (Hirasaka) G. Hansen \& Moestrup, based on morphologic, ultrastructural, and phylogenetic relationships among a large assemblage of gymnoid-type dinoflagellates (Daughberg et al. 2000). It is cosmopolitan in its distribution and has been observed to form blooms in coastal ecosystems around the world (Robinson \& Brown 1983, Fukuyo et al. 1990, Hallegraeff 1991, Voltolina 1993, Horner et al. 1997, Lu \& Hodgkiss 2004, Feyzioğlu \& Öğü 2006), including the Gulf of Mexico and the Atlantic coast of North America (Steidinger \& Williams 1970, Robichaux et al. 1998, Steidinger et al. 1998, Badylak \& Phlips

\footnotetext{
*Corresponding author: Edward J. Phlips; E-mail, phlips@ufl.edu
}

2004, Badylak et al. 2007, Phlips et al. 2011, 2012). Blooms of $A$. sanguinea have been associated with mass mortalities of invertebrates and fish in various regions of the world (Cardwell et al. 1979, Jordán 1979, Harper \& Guillen 1989, Shumway 1990, Kahru et al. 2004). In the Gulf of Mexico, blooms of $A$. sanguinea were the suspected cause of fish kills and marine mammal stranding in the mid-1990's (Robichaux et al. 1998, Steidinger et al. 1998). Harmful effects of $A$. sanguinea on the behavior, physiology and survival of marine invertebrates have also been demonstrated in laboratory experiments (Fiedler 1982, Bricelj et al. 1992, Botes et al. 2002).

This paper focuses on observations during bloom events of $A$. sanguinea in the Caloosahatchee Estuary in southwest Florida. Corresponding salinity, temperature, total nitrogen, and total phosphorus values are reported and discussed within the context of possible factors related to $A$. sanguinea dynamics. The results of this study and recent observations of regular blooms of $A$. sanguinea in a number of other Florida estuaries, including the Indian River Lagoon (Phlips et al. 2010, 2011) and the St. Lucie Estuary (Phlips et al. 2012), highlight the importance of this species in the subtropical environments of the Gulf of Mexico 


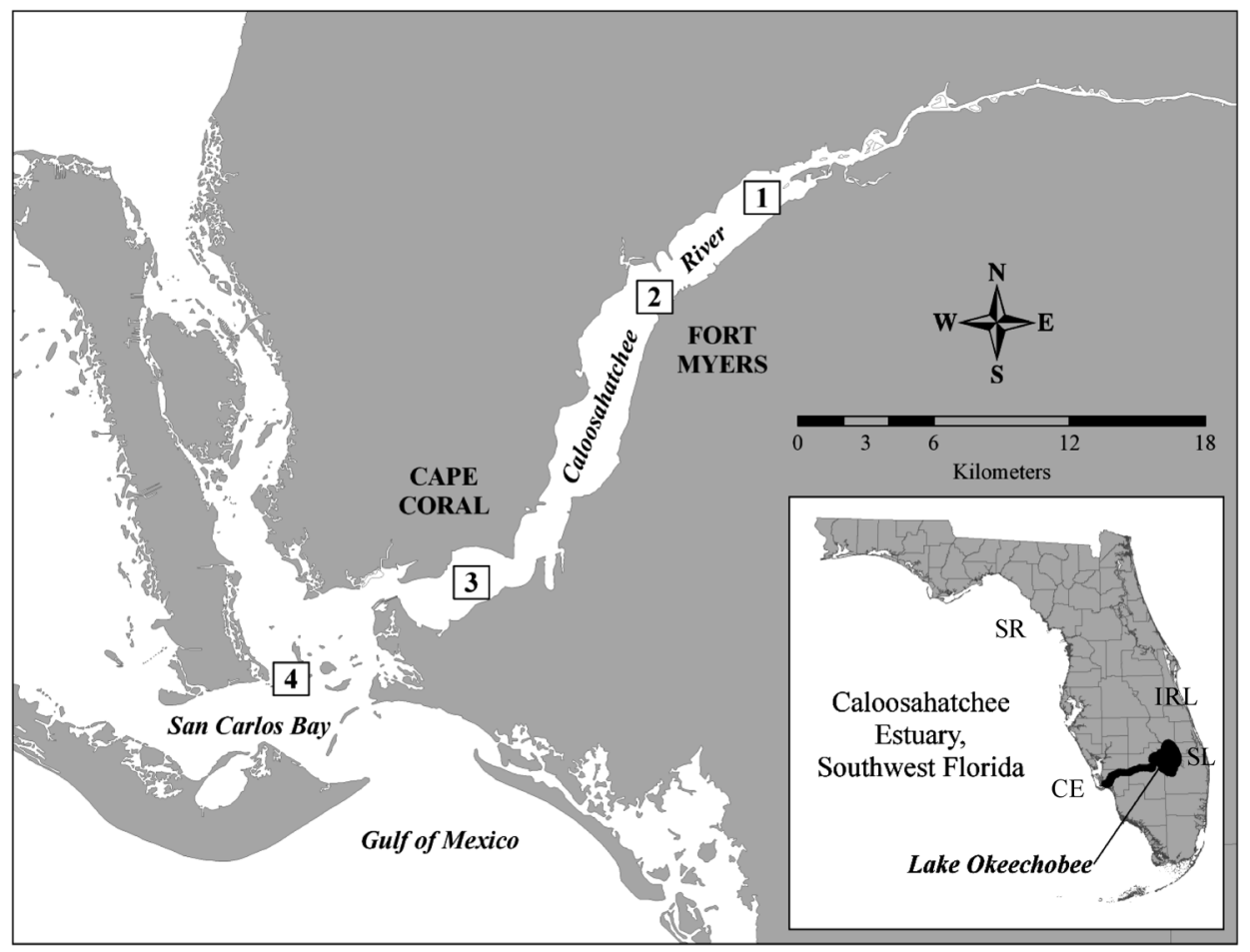

Fig. 1. Map of the study area showing Sites 1,2 and 3 in the estuary and Site 4 in San Carlos Bay. Locations of the Caloosahatchee Estuary (CE), Suwannee River Estuary (SR), Indian River Lagoon (IRL) and St. Lucie Estuary (SL) are shown in the insert map of Florida.

and the east coast of Florida, and provide further evidence of its tolerance to a wide range of environmental conditions.

\section{Materials and Methods}

\section{Study site description}

Caloosahatchee Estuary is located in the southwest coastal region of Florida adjacent to the Gulf of Mexico, latitude $26^{\circ} 34^{\prime} \mathrm{N}$ and longitude $81^{\circ} 55^{\prime} \mathrm{W}$ (Fig. 1). It is connected to Lake Okeechobee via the Caloosahatchee River. The estuary experiences periodic freshwater flushing events during the rainy season (May-October), including inputs of nutrient-rich water from Lake Okeechobee, Florida's largest freshwater lake, causing significant variability of salinity (Doering et al. 2002).

\section{Field collections and measurements}

Samples were collected once a month at four sites in the PM hours near mid-afternoon from February 2009 through February 2010. Sites 1 and 2 were located in the upper region of the estuary, Site 3 was in the mid-estuary, and Site 4 was in San Carlos Bay (Fig. 1). Water was collected with an integrating sample tube, which captures water evenly from the surface to $0.1 \mathrm{~m}$ above the bottom sediments. Water depths at the sampling sites were approximately 3 meters. Multiple tubes of water were combined in a mixing tub to achieve a volume of approximately $10 \mathrm{~L}$. Samples for phytoplankton analysis and water chemistry were subdivided on site. Phytoplankton samples were preserved with Lugol's fixative. Samples for nutrient analyses were kept on ice and frozen upon return to the laboratory. Temperature and salinity were measured on site with a $\mathrm{HACH}$ HQ40d (Loveland, Colorado, USA) multi-environmental probe at the surface and near the bottom.

\section{Water analyses}

Total nitrogen (TN) and total phosphorus (TP) were determined from unfiltered samples using the persulfate digestion method (SM4500-N-C and SM4500-P-B5 \& E) (APHA 1995). Sample processing and analyses followed the guidelines set forth by the laboratories of the Florida Department of Health/DEP-approved Quality Assurance/ Quality Control Plan, NELAP Certification E72883.

\section{Light microscopy}

Phytoplankton composition was determined using a Leica DMIL phase contrast inverted microscope (Leica Microsystems, Wetzler, Germany) from samples collected at each site. Phytoplankton composition and morphological variants of Akashiwo sanguinea were enumerated using the Utermohl settling method (Utermohl 1958). Phytoplankton composition was analyzed at $400 \mathrm{x}$ and $100 \mathrm{x}$ magnifications. Cells $<30 \mu \mathrm{m}$ were counted at $400 \mathrm{x}$ and an entire bottom count of the settling chamber was com- 
pleted at 100x for phytoplankton species $>30 \mu \mathrm{m}$ in size. Morphologies of $A$. sanguinea were identified and counted at 100X. Images of typical $A$. sanguinea cells were taken with a Leica DFC 320 (Leica Ltd. Cambridge, UK).

Fluorescence microscopy was used to enumerate picoplanktonic cyanobacteria at 1000x magnification (Phlips et al. 1999). Subsamples of seawater were filtered onto $0.2 \mu \mathrm{m}$ Nucleopore filters and mounted between a microscope slide and cover slip with immersion oil.

Cell biovolumes were estimated by assigning combinations of geometric shapes to fit the characteristics of individual taxa (Smayda 1978). Specific phytoplankton dimensions were measured for at least 30 randomly selected cells. Species that vary in size, such as many diatom species, were placed into size categories.

Figures involving phytoplankton were expressed as biovolume to provide a better view of the relative biomass contribution of different groups or locations.

\section{Results}

\section{Field measurements and water chemistry}

Surface water temperatures ranged from $14^{\circ} \mathrm{C}$ in the winter of 2010 to $32^{\circ} \mathrm{C}$ in the summer of 2009 , and did not differ by more than $2^{\circ} \mathrm{C}$ between sites (Fig. 2).
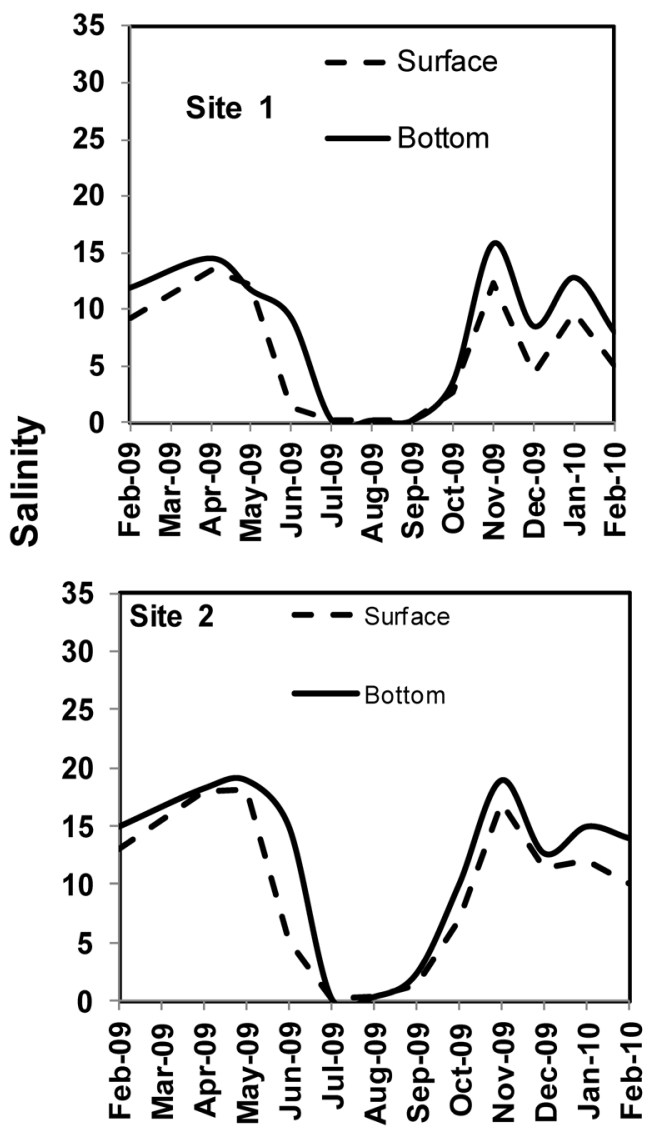

Salinities ranged from near 0 in July-September at Sites 1 and 2 in the upper estuary to near 35 in May at Site 4 in the bay (Fig. 3). There was a substantial decline in salinity in response to the onset of the rainy season in May and June at Sites 1, 2 and 3. Vertical stratification of salinity was observed in June at Sites 1 and 2, and in September

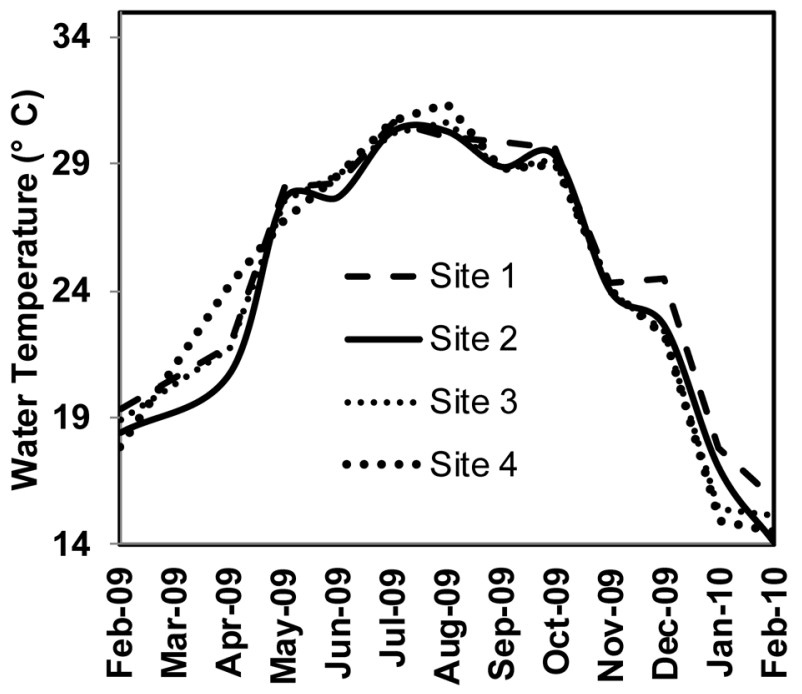

Fig. 2. Surface water temperatures at the four sampling sites.
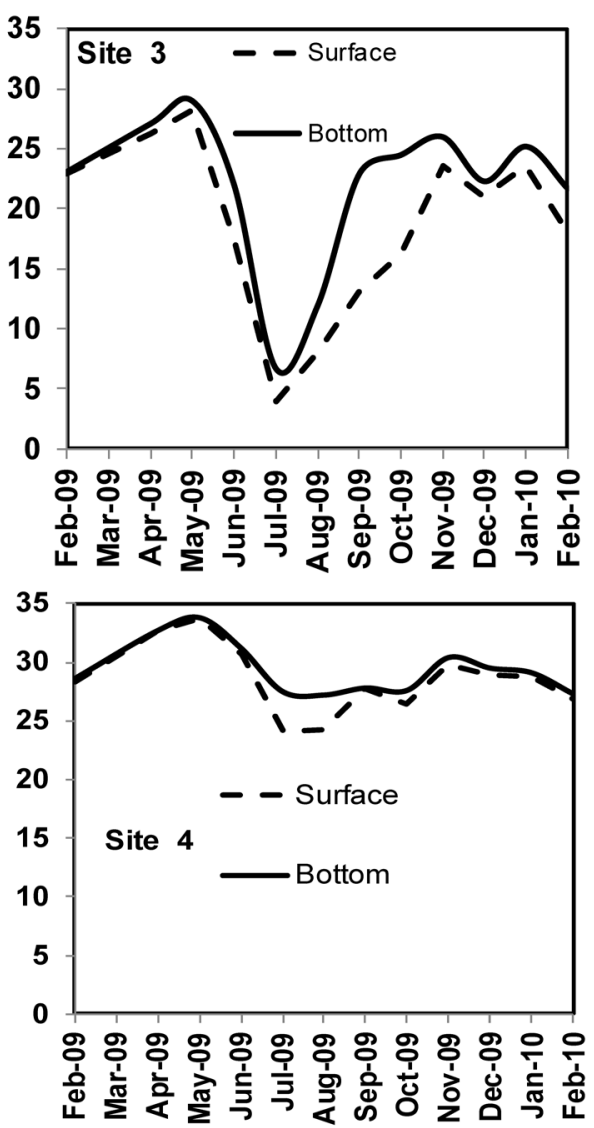

Fig. 3. Salinities at the water surface and near the bottom of the water column at the four sampling sites. 

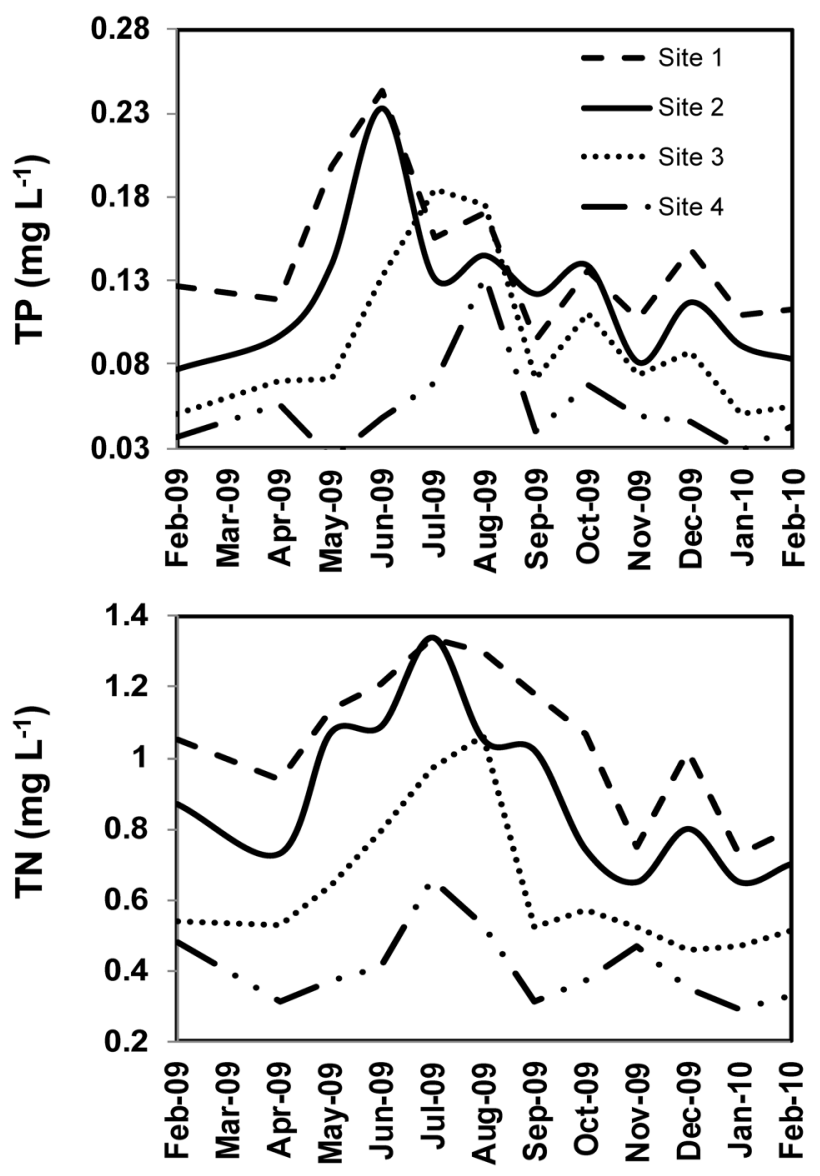

Fig. 4. Total phosphorus (TP) (upper) and total nitrogen (TN) (lower) concentrations at the four sampling sites.

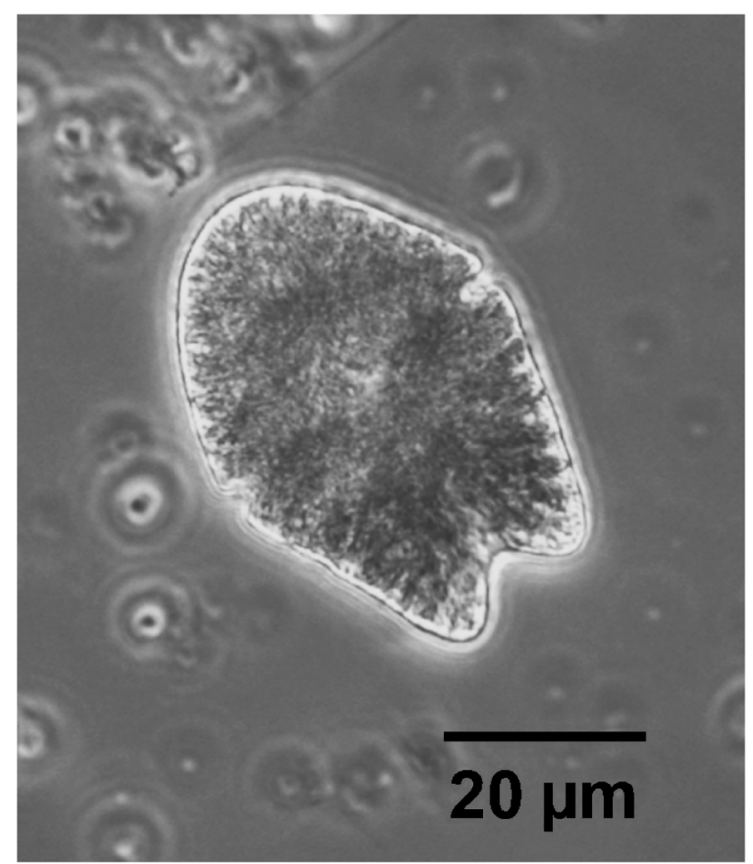

Fig. 5. Light microscope image of a typical Lugol's-preserved Akashiwo sanguinea cell.

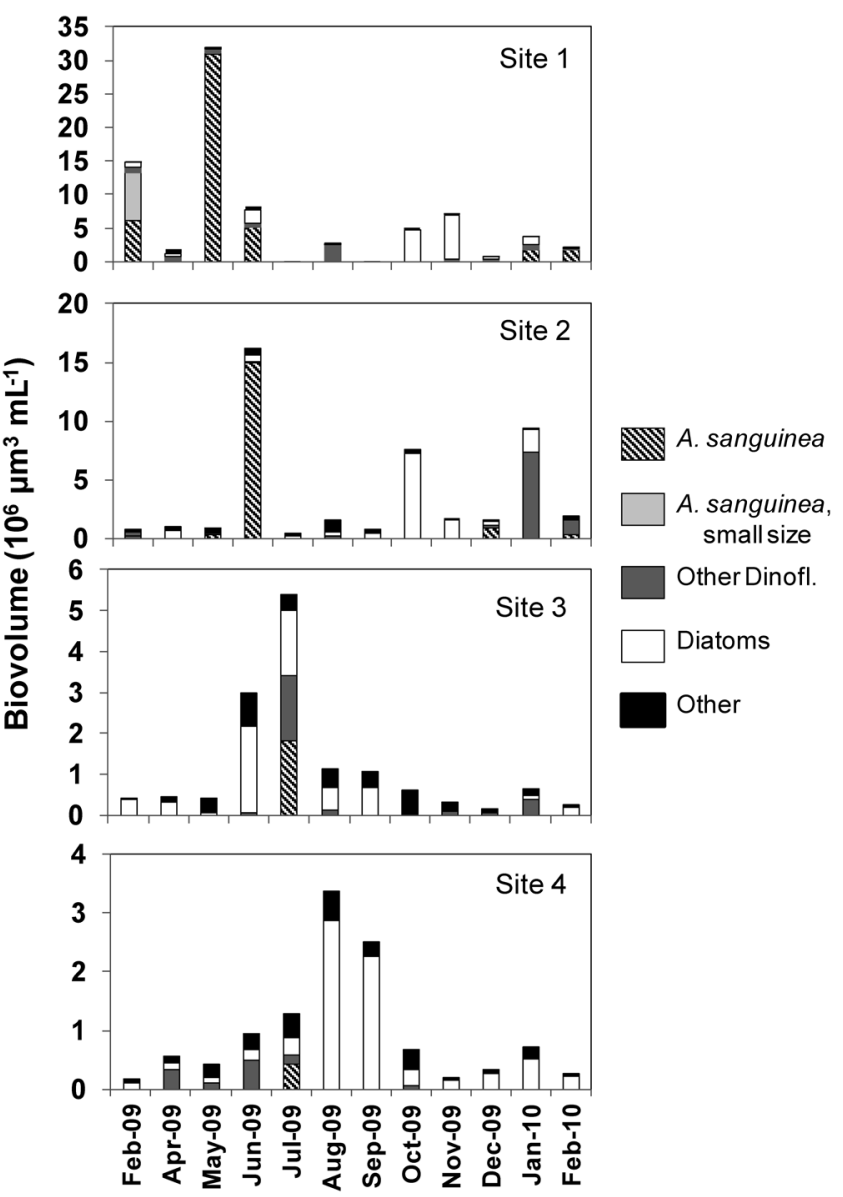

Fig. 6. Monthly phytoplankton biovolume of five groupings of phytoplankton, i.e. Akashiwo sanguinea, small-sized Akashiwo sanguinea, other dinoflagellate species, diatoms, and all other taxa (Other). Note there was no sampling in March 2009.

and October at Site 3.

Total phosphorus (TP) concentrations peaked in June during the beginning of the rainy season at Sites 1 and 2 (Fig. 4). TP concentrations at Sites 3 and 4 peaked in July and August. Total nitrogen (TN) concentrations peaked in July-August at all four sites (Fig. 4).

\section{Akashiwo sanguinea morphology during bloom events}

Vegetative cells of $A$. sanguinea typically had a broad conical epicone and bilobed hypocone (Fig. 5). Typical vegetative cells ranged in size from $41 \mu \mathrm{m}$ to $64 \mu \mathrm{m}$ in length and $32 \mu \mathrm{m}$ to $53 \mu \mathrm{m}$ in width. During some sampling periods there were high densities of smaller sized vegetative cells, ranging in size from $32 \mu \mathrm{m}$ to $36 \mu \mathrm{m}$ in length and $22 \mu \mathrm{m}$ to $28 \mu \mathrm{m}$ in width. Small $A$. sanguinea cells have also been observed to periodically dominate bloom populations of $A$. sanguinea in Louisiana, USA (Robichaux et al. 1998).

\section{Akashiwo sanguinea abundance and biovolume}

Biomass of $A$. sanguinea, expressed as biovolume, 


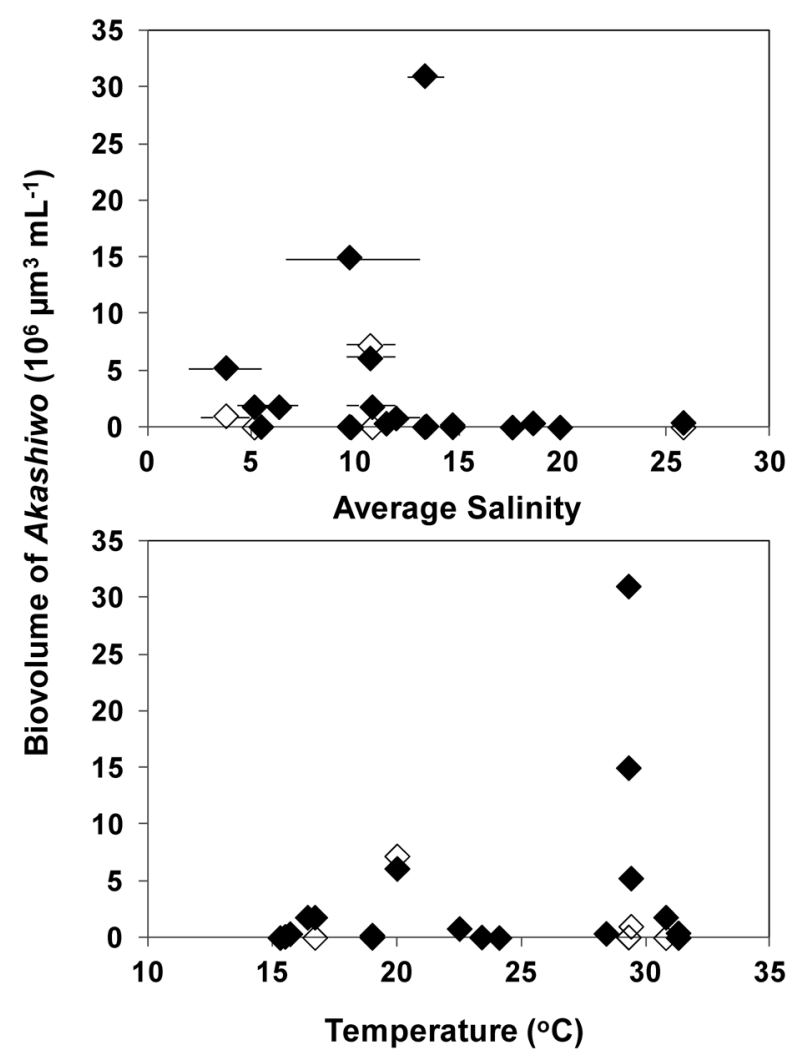

Fig. 7. Distribution of Akashiwo sanguinea (expressed as biovolume) in relation to average water column salinity (upper) and surface water temperature (lower). Closed symbols represent typical vegetative cells, and open symbols represent smaller vegetative cells. Since salinity varied with depth on some sampling dates, ranges of values are shown as horizontal lines next to the average values. No significant vertical stratification in temperature was observed

peaked in the first half of 2009, most prominently at Sites 1 and 2 (Fig. 6). Major blooms of A. sanguinea were observed in February, June and July at Site 1, and in June at Site 2. In these bloom samples, A. sanguinea represented over $90 \%$ of total phytoplankton biovolume. Akashiwo sanguinea contributed to the biovolume at Site 3 and 4 in July, but these samples also contained significant amounts of other taxa, including other dinoflagellates and diatoms. During the second half of the sampling period, total phytoplankton biovolume did not reach the same levels as in the first half of 2009, and diatoms were generally the dominant taxa, except for a bloom of another dinoflagellate species at Site 2 in January 2010 (Fig. 6). Peak total phytoplankton biovolumes at Sites 3 and 4 were substantially lower than at Sites 1 and 2 in the upper estuary. At Site 4 in San Carlos Bay diatoms were generally dominant, peaking in $\mathrm{Au}-$ gust and September.

Akashiwo sanguinea were observed over a wide range of salinities (i.e. 1-28), but the highest biovolumes were observed between 9 and 16 (Fig. 7). The highest biovolume was near $30.5 \times 10^{6} \mu \mathrm{m}^{3} \mathrm{~mL}^{-1}$, equivalent to 740 cells $\mathrm{mL}^{-1}$

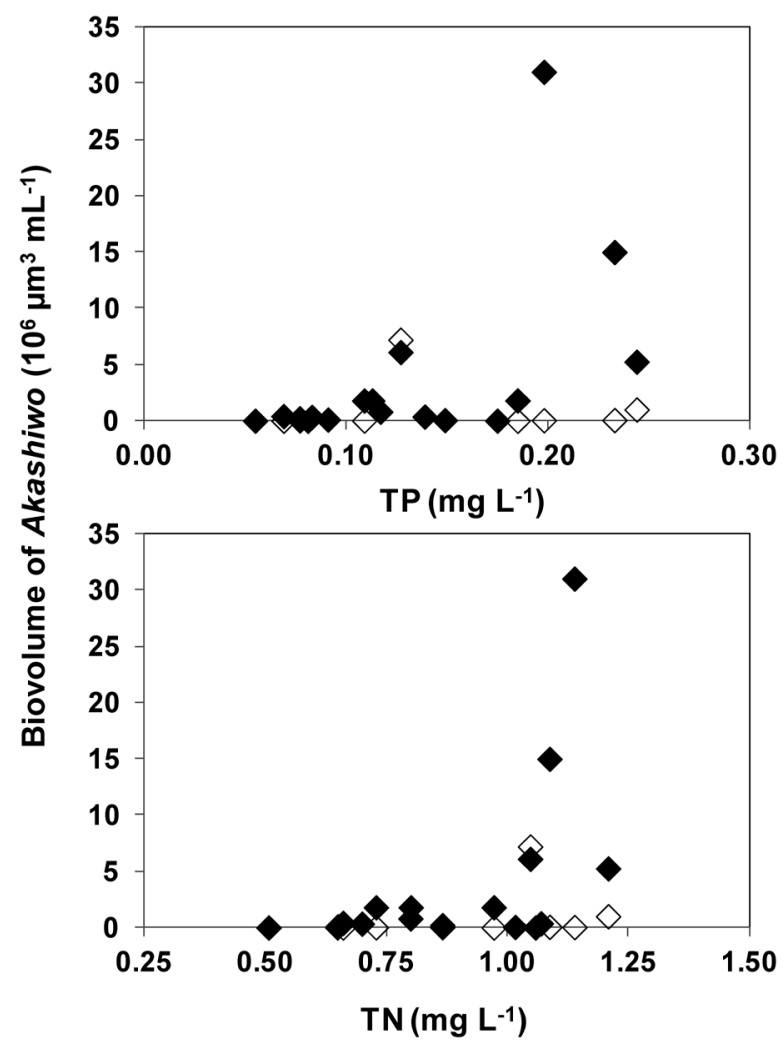

Fig. 8. Distribution of Akashiwo sanguinea cell densities in relation to total phosphorus concentration (TP) (upper) and total nitrogen (TN) (lower). Closed symbols represent typical vegetative cells, and open symbols smaller vegetative cells.

of typical vegetative cells. The latter salinities were characteristic of the upper estuary, which receives freshwater inputs from the watershed.

Akashiwo sanguinea was observed at temperatures from $15^{\circ} \mathrm{C}$ to $32^{\circ} \mathrm{C}$ (Fig. 7). High biovolumes were observed between $24-29^{\circ} \mathrm{C}$. The highest cell densities of small sized $A$. sanguinea cells (i.e. 627 cells $\mathrm{mL}^{-1}$ ) were observed in February, when water temperature was $19^{\circ} \mathrm{C}$.

Akashiwo sanguinea was observed over a wide range of total phosphorus (TP) concentrations (i.e. $0.03-0.21 \mathrm{mg} \mathrm{L}^{-1}$ ) and total nitrogen (TN) concentrations (i.e. $0.4-1.3 \mathrm{mg} \mathrm{L}^{-1}$ ) (Fig. 8). Peak biovolumes were observed at the upper end of nutrient concentrations, which coincided with the onset of spring rains. Peak cell densities of small-sized $A$. sanguinea cells were associated with somewhat lower TP and TN concentrations in February. The latter trend compliments the observations of several researchers, reporting that reduced cell size in some dinoflagellate species is associated with periods of low nutrient concentrations (Silva \& Faust 1995, Smayda 2010).

\section{Discussion}

Since the first report of Akashiwo sanguinea blooms in 


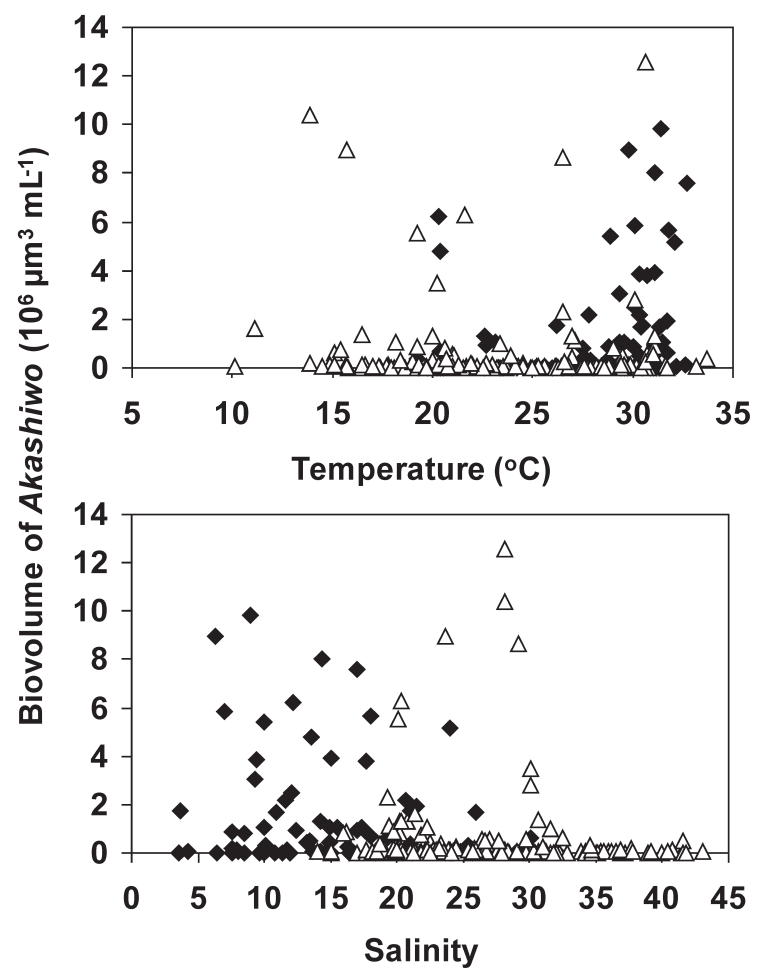

Fig. 9. Distribution of Akashiwo sanguinea biovolumes in relation to water temperature (upper) and salinity (lower) in two major estuaries in Florida, the St. Lucie (filled symbols) and the Indian River Lagoon (open symbols) (after Phlips et al. 2011 and 2012).

Japan in the early $20^{\text {th }}$ century, the majority of bloom observations have come from temperate environments, including the California coast (Horner et al. 1997, Rines et al. 2010), New Jersey coast in the U.S. (Martin 1928), Esquimart in Canada (Voltolina 1993), the Black Sea (Gómez \& Boicenco 2004), Venice (Voltolina 1975), Liverpool Bay (Voltolina et al. 1986) and the Ariake Sea in Japan (Matsubara et al. 2007). However, given its eurythermal character (Matsubara et al. 2007) it is not surprising that $A$. sanguinea blooms have also been observed in subtropical and tropical ecosystems in Brazil (Domingos \& Menezes 1998) and Hong Kong Bay (Lu \& Hodgekiss 2004). The observation of $A$. sanguinea blooms in the Caloosahatchee Estuary adds to the list of subtropical/ tropical ecosystems where these species play an important role in phytoplankton community structure and dynamics. The current study compliments other recent reports of $A$. sanguinea blooms in a number of other estuaries along the coast of Florida, including the northern Indian River Lagoon (Phlips et al. 2011), the northern St. Lucie Estuary (Phlips et al. 2012) and Apalachicola Bay (Viveros \& Phlips, unpublished data). The eurythermal nature of $A$. sanguinea in Florida is illustrated by the wide range of temperatures over which blooms have been observed in the aforementioned ecosystems (Fig. 9).
One feature shared by the Florida ecosystems subject to A. sanguinea blooms is the presence of significant freshwater inflows from terrestrial watersheds that depress salinities and introduce external nutrients. The well-documented euryhaline character of A. sanguinea (Matsubara et al. 2007, Shikata et al. 2008) likely contributes to the species' success in these ecosystems. The importance of this feature of $A$. sanguinea is further illustrated by the observation that blooms in several Florida estuaries have been observed over a broad range of salinities below oceanic levels (i.e. 35) (Fig. 9).

From a hydrologic perspective another feature that appears to contribute to A. sanguinea blooms in the aforementioned Florida ecosystems, including the Caloosahatchee Estuary, is the existence of periods of relatively long water residence times that provide the temporal window needed for the accumulation of biomass (Phlips et al. 2011, 2012). By contrast, blooms of $A$. sanguinea have rarely been observed in well-flushed estuaries in Florida, such as the Suwannee River Estuary (Quinlan et al. 2007), the central Indian River Lagoon (Phlips et al. 2010), the southern St. Lucie Estuary (Phlips et al. 2012) and the outer estuary of the St. Johns River (Cichra \& Phlips, unpublished data).

In terms of the relationships between nutrient concentrations and A. sanguinea biomass in the Caloosahatchee Estuary, the most intense blooms of large sized vegetative cells were observed during a period of elevated nutrient concentrations during the first two months of the rainy season (i.e. May and June) (Fig. 4). Later in the rainy season phytoplankton biovolume in the upper estuary declined, as salinities dropped to near freshwater levels (Fig. 3), which likely inhibited the growth of $A$. sanguinea. The sensitivity of $A$. sanguinea to rapid and substantial declines in salinity (i.e. to less than or equal to 5) has been previously observed by Shikata et al. (2008). In addition, high freshwater discharge rates during the peak of the rainy season reduce water residence times, precluding the accumulation of phytoplankton biomass. Similar relationships have been observed in other Florida estuaries (Robichaux et al. 1998, Phlips et al. 2011, 2012), as well as estuaries in other regions of the world (Lam \& Ho 1989, Voltolina 1993). The specific role of nitrogen enrichment in enhancing the potential for A. sanguinea blooms has been highlighted in several studies (García-Hernández et al. 2005, Rothenberger 2007, Kudela et al. 2008). The importance of periodic nutrient limitation of phytoplankton production has been demonstrated in many coastal ecosystems in Florida, such as the Indian River Lagoon (Phlips et al. 2002), Suwannee River (Bledsoe \& Phlips 2000) and the St. Lucie estuary (Phlips et al. 2012). The elevated densities of small-celled forms of $A$. sanguinea during periods of lower TP concentrations suggests that the Caloosahatchee may be subject to periods of phosphorus and nitrogen limitation, as suggested by Buzzelli et al. (2013).

The aforementioned correlations between A. sanguinea and selected environmental variables (e.g. salinity, temper- 
ature, nutrient concentrations) provide some insights into the environmental preferences and tolerances of the species, but clearly do not provide a comprehensive list of potential driving factors for bloom events or successional patterns, which involve a wider range of considerations. For example, it has been suggested that high abundances of certain diatom, raphidophyte and dinoflagellate species may inhibit the growth of $A$. sanguinea through allelopathic interactions (Yamasaki et al. 2007, Matsubara et al. 2008, Qiu et al. 2011).

Another feature of $A$. sanguinea that may contribute to its success in a wide range of estuaries around the world is the production of extracellular mucous. Akashiwo sanguinea has been observed to produce prodigious quantities of mucilage, with estimates of up to $50 \%$ of photosynthate (Smayda 2002) excreted through pores in the cell surface (Badylak \& Phlips, unpublished data). Smayda (2002) has suggested that the excretion of mucous by dinoflagellates alters the physical and chemical structure of the water column, including the reduction of water column turbulence, which in turn favors the formation of blooms. Other researchers have suggested that the excretion of mucous by algae provide advantages in terms of nutrient availability, competition with other phytoplankton species and reduction of grazing losses (Reynolds 2006). The presence of large quantities of mucilage may also contribute to observed negative impacts of $A$. sanguinea on other plankton, pelagic fauna and benthic organisms, as observed for other mucous producing algal species (Shumway 1990, Buskey \& Hyatt 1995, Liu \& Buskey 2000, Botes et al. 2002).

From a global perspective the eurythermal, euryhaline and mucous producing features of $A$. sanguinea help to explain its cosmopolitan distribution. In the subtropical estuaries of Florida subject to large freshwater inflows, the eurythermal and euryhaline character of $A$. sanguinea make it a competitive species throughout the year, yielding bloom events inside and outside the more typical warm season peak period of phytoplankton biomass in many Florida ecosystems. In Florida, this pattern is in contrast to bloom events of another major HAB species in Florida estuaries, the toxic dinoflagellate Pyrodinium bahamense, which is typically restricted to temperatures in excess of $25^{\circ} \mathrm{C}$, reflecting the tropical nature of the species (Phlips et al. 2006). Akashiwo sanguinea is indeed an alga for all seasons.

\section{Acknowledgements}

We thank Dan Stephens, Karen Stephens and Joe Mathews for all their help and dedication in the field. The research was funded by the South Florida Water Management District.

\section{References}

APHA (1995) Standard methods for the examination of water and wastewater. 19th ed. American Public Health Assoc., Washington, DC.

Badylak S, Phlips EJ (2004) Spatial and temporal patterns of phytoplankton composition in a subtropical lagoon, the Indian River Lagoon, Florida, USA. J Plankton Res 26: 1229-1247.

Badylak S, Phlips EJ, Baker P, Fajans J, Boler R (2007) Distributions of phytoplankton in Tampa Bay estuary, U.S.A. 20022003. Bull Mar Sci 80: 295-317.

Bledsoe EL, Phlips EJ (2000) Relationships between phytoplankton standing crop and physical, chemical and biological gradients in the Suwannee River and plume region, U.S.A. Estuaries 23: 458-473.

Botes L, Smit AJ, Cook PA (2002) The potential threat of algal blooms to the abalone (Haliotis midae) mariculture industry situated around the South African coast. Harmful Algae 2: 247-259.

Bricelj VM, Ford SM, Borrero FJ (1992) Unexplained mortalities of hatchery-reared juvenile oysters, Crassastrea virginica (Gmelin). J Shellfish Res 11: 331-347.

Buskey EJ, Hyatt CJ (1995). Effects of the Texas (USA) brown tide alga on planktonic grazers. Mar Ecol Prog Ser 126: 285292.

Buzzelli, C, Boutin B, Ashton M, Welch B, Gorman P, Wan Y, Doering P (2013) Fine-scale detection of estuarine water quality with managed freshwater releases. Est Coast, DOI 10.1007/ s12237-013-9751-8.

Cardwell RD, Olsen S, Carr MI, Sanborn EW (1979) Causes of oyster mortality in South Puget Sound. NOAA Technical Report, ERL MESA-39.

Daughberg N, Hansen G, Moestrup Ø (2000) Phylogeny of some of the major genera of dinoflagellates based on ultrastructural and partial LSU rDNA sequence data, including the erection of three new genera of unarmored dinoflagellates. Phycologia 39: 302-317.

Doering PH, Chamberlain RH, Haunert DE (2002) Using submerged aquatic vegetation to establish minimum and maximum freshwater inflows to the Caloosahatchee Estuary, Florida. Estuaries 25: 1343-1354.

Domingos P, Menezes Mariânge la (1998) Taxonomic remarks on planktonic phytoflagellates in a hypertrophic tropical lagoon (Brazil). Hydrobiologia 369/370: 297-313.

Fiedler PC (1982) Zooplankton avoidance and reduced grazing responses to Gymnodinium splendens (Dinophyceae). Limnol Oceanogr 27: 961-965.

Feyzioğlu AM, Öğüt H (2006) Red tide observations along the Eastern Black Sea coast of Turkey. Turk J Bot 30: 375-798.

Fukuyo Y, Takano H, Chihara M, Matsuoka K (1990) Red Tide Organisms in Japan: An Illustrated Taxonomic Guide. Uchida Rokakuho, Tokyo, 407 pp.

García-Hernández G, Garćia-Rico L, Jara-Marini ME, BarrazaGuardado R, Weaver AH (2005) Concentrations of heavy metals in sediment and organisms during a harmful algae bloom (HAB) at Kun Kaak Bay, Sonora Mexico. Mar Pollut Bull 50: 733-739.

Gómez F, Boicenco L (2004) An annotated checklist of dinofla- 
gellates in the Black Sea. Hydrobiologia 517:43-59.

Hallegraeff GM (1991) Aquaculturists' Guide to Harmful Australian Microalgae. CSIRO Division of Fisheries, Hobart, Australia, $136 \mathrm{pp}$.

Harper DE, Guillen G (1989) Occurrence of a dinoflagellate bloom associated with an influx of low salinity water at Galveston Texas, and coincident mortalities of demersal fish and benthic invertebrates. Contrib Mar Sci 31: 147-161.

Hirasaka K (1922) Honnen shunki ni okoreru akasiwo [Red tides in the spring of this year]. Zool Mag 34: 740-48. (in Japanese)

Horner RA, Garrison DL, Plumley FG (1997) Harmful algal blooms and red tide problems on the U.S. west coast. Limnol Oceanogr 42: 1076-1088.

Jordán R (1979) Hematotalasia y mortandad de peces en la costa peruana. Bol ERFEM 3: 34-37.

Kahru M, Mitchell G, Diaz A, Miura M (2004) MODIS detects a devastating algal bloom in Paracas Bay, Peru. EAS Trans AGU 85: 493-509.

Kudela R, Lane J, Cochlan W (2008) The potential role of anthropogenically derived nitrogen in the growth of harmful algae in California, USA. Harmful Algae 8: 103-110.

Lam CWY, Ho KC (1989) Red tides in Holo Harbour Hong Kong. In: Red Tides Biology, Environmental Science and Toxicology (eds Okaichi T, Anderson DM, Nemoto T). Elsevier Press, New York, pp. 49-52.

Liu H, Buskey EJ (2000) The exopolymer secretions (EPS) layer surrounding Aureoumbra lagunensis cells affects growth, grazing and behavior of protozoa. Limnol Oceanogr 45: 11871191.

Lu SH, Hodgkiss IJ (2004) Harmful algal bloom causative collected from Hong Kong waters. Hydrobiologia 512: 231-238.

Martin GW (1928) Dinoflagellates from marine and brackish waters of New Jersey. Univ Iowa Stud Nat Hist 12: 1-32.

Matsubara T, Nagasoe S, Yamasaki Y, Shikata T, Shimasaki Y, Oshima Y, Honjo T (2007) Effects of temperature, salinity, and irradiance on the growth of the dinoflagellate Akashiwo sanguinea. J Exp Mar Bio Ecol 342: 226-230.

Matsubara T, Nagasoe S, Yamasaki Y, Shikata T, Shimasaki Y, Oshima Y, Honjo T (2008) Inhibitory effects of centric diatoms on the growth of the dinoflagellate Akashiwo sanguinea. Nippon Suisan Gakkaishi 74: 598-606.

Phlips EJ, Badylak S, Bledsoe E, Cichra M (2006) Factors affecting the distribution of Pyrodinium bahamense var. bahamense in coastal waters of Florida. Mar Ecol Prog Ser 322: 99-115.

Phlips EJ, Badylak S, Christman MC, Lasi MA (2010) Climatic trends and temporal patterns of phytoplankton composition, abundance and succession in the Indian River Lagoon, Florida, USA. Est Coast 33: 498-512.

Phlips EJ, Badylak S, Christman M, Wolny J, Garland J, Hall L, Hart J, Landsberg J, Lasi M, Lockwood J et al. (2011) Scales of variability of harmful algae blooms in the Indian River, Florida, USA. Harmful Algae 10: 277-290.

Phlips EJ, Badylak S, Grosskopf T (2002) Factors affecting the abundance of phytoplankton in a restricted subtropical lagoon, the Indian River Lagoon, Florida, U.S.A. Est Coast Shelf Sci 55: 385-402.

Phlips EJ, Badylak S, Hart J, Haunert D, Lockwood J, Manley H, O’Donnell K, Yilmaz M (2012) Climatic influences on autoch- thonous and allochthonous phytoplankton blooms in a subtropical estuary, St. Lucie Estuary, Florida, USA. Est Coast 35: 335-352.

Phlips EJ, Badylak S, Lynch TL (1999) Blooms of the picoplanktonic cyanobacterium Synechococcus in Florida Bay. Limnol Oceanogr 44: 1166-1175.

Qiu X, Yamasaki Y, Shimasaki Y, Gunjikake H, Matsubara T, Nagasoe S, Oshima Y, Honjo T, Etoh T, Matsui S, Honjo T, Oshima Y (2011) Growth interactions between the raphidophyte Chattonella antiqua and the dinoflagellate Akashiwo sanguinea. Harmful Algae 11: 81-87.

Quinlan EL, Phlips EJ (2007) Phytoplankton assemblages across the marine to low-salinity zone in a blackwater dominated estuary. J Plankton Res 29: 410-416.

Reynolds CS (2006) Ecology of Phytoplankton. Cambridge University Press, Cambridge, 535 pp.

Rines JEB, McFarland MN, Donaghay PL, Sullivan JM (2010) Thin layers and species-specific characterization of the phytoplankton community in Monterey Bay, California, USA. Continental Shelf Res 30: 66-80.

Robichaux RJ, Dortch Q, Wrenn JH (1998) Occurrence of Gymnodinium sanguineum in Texas and coastal waters. In: Characteristics and Causes of Texas Marine Strandings (ed Zimmerman R). NMFS 143, NOAA Technical Report, pp. 19-25.

Robinson MG, Brown LN (1983) A recurrent red tide in a British Columbia coastal lagoon. Can J Fish Aquat Sci 40: 2135-2143.

Rothenberger MB (2007) Long term impacts of changing land use practices on water quality and phytoplankton assemblages in the Neuse Estuary ecosystem South Carolina. PhD. Dissertation, Department of Plant Biology, North Carolina State University, Raleigh, NC, USA.

Shikata T, Nagasoe S, Oh S, Matsubara, T, Yamasaki Y, Shimasaki, Y, Oshihima Y, Honjo T (2008) Effects of down- and upshocks from rapid changes of salinity on survival and growth of estuarine phytoplankters. J Fac Agr Kyushu Univ 53: 81-87.

Shumway SE (1990) A review of the effects of algal blooms on shellfish and Aquaculture J World Aquacul Soc 21: 65-104.

Silva ES, Faust MA (1995) Small cells in the life history of dinoflagellates (Dinophyceae): a review. Phycologia 34: 396-408.

Smayda TJ (1978) From phytoplankters to biomass. In: Phytoplankton Manual (ed Sournia A), UNESCO, Paris, pp. 273279.

Smayda TJ (2002) Turbulence, water mass stratification and harmful algal blooms: an alternative view and frontal zones as “pelagic seed banks". Harmful Algae 1: 95-112.

Smayda TJ (2010) Adaptations and selection of harmful and other dinoflagellate species in upwelling systems 1. Morphology and adaptive polymorphism. Prog Oceanogr 85: 53-70.

Steidinger KA, Tangen K (1996) Dinoflagellates. In: Identifying Marine Diatoms and Dinoflagellates (ed Tomas CR). Academic Press, San Diego, pp. 387-598.

Steidinger KA, Stockwell DA, Truby EW, Wardle WJ, Dortch Q, Van Dolan FM (1998) Phytoplankton blooms off Louisiana and Texas, May-June 1994. In: Characteristics and causes of Texas marine strandings (ed Zimmerman R). NMFS 143, NOAA Technical Report, pp. 13-17.

Steidinger KA, Williams J (1970) Dinoflagellates. Memoirs of the Hourglass Cruises. Florida Department of Natural Re- 
sources, St. Petersburg, FL, USA.

Utermohl H (1958) Zur vervollkommnung der quantitativen phytoplankton-methodik. Miteilungen- Internationale Vereinigung für Theoretische und Angewandte Limnologie 9: 1-38.

Voltolina D (1975) The phytoplankton of the lagoon of Venice: November 1971-November 1972. Pubbl Staz Zool Napoli 39: 206-340.

Voltolina D (1993) The origin of recurrent blooms of Gymnodinium sanguineum (Hirasaka) in a shallow lagoon. J Exp Mar
Biol Ecol 168: 217-222.

Voltolina D, Beardall J, Foster P (1986) The phytoplankton of Liverpool Bay (1977-1978). 4. Quantitative distributions and seasonal variations. Nova Hedwig 43: 11-28.

Yamasaki Y, Nagasoe S, Matsubara T, Shikata T, Shimasaki Y, Oshima Y, Honjo T (2007) Growth inhibition and formation of morphologically abnormal cells of Akashiwo sanguinea (Hirasaka) G. Hansen et Moestrup by cell contact with Cochlodinium polykrikoides Margalef. Mar Biol 152: 157-163. 